Journal of Mathematics and Statistics 3 (3): 112-115, 2007

ISSN 1549-3644

(C) 2007 Science Publications

\title{
Generalization of Banach Contraction Principle in Two Directions
}

\author{
${ }^{1}$ E. El-Shobaky, Sahar Mohamed Ali, and ${ }^{2}$ Montaser Saudi Ali \\ ${ }^{1}$ Department of Mathematics, Faculty of Science, Ain Shams University, Cairo, Egypt \\ ${ }^{2}$ Department of Mathematics, Faculty of Education, Ain Shams University, Cairo, Egypt
}

\begin{abstract}
We showed that the generalized contraction mapping defined on a closed convex subset of a weakly Cauchy normed space has a unique fixed point. Moreover, the sequence of iterates of any element in the domain of the given mapping is converging strongly to the fixed point of such a mapping.
\end{abstract}

Key words: $\{a, b, c\}$-contraction mapping,Banach contraction principle, weakly Cauchy normed spaces.

\section{INTRODUCTION}

In $1922 \mathrm{~S}$. Banach proved the famous known Banach contraction principle, if $\mathrm{X}$ is a complete metric space and $\mathrm{T}$ is a contraction mapping of $\mathrm{X}$ into itself. Then $\mathrm{T}$ has a unique fixed point $\mathrm{y} \in \mathrm{X}$. Moreover, the sequence of iterates $\left\{\mathrm{T}^{\mathrm{n}}(\mathrm{x})\right\}_{\mathrm{n}} \in \mathrm{N}$ is strongly convergent to $\mathrm{y}$ for every $\mathrm{x} \in \mathrm{X}$.

In recent years, rapid developments have occurred in many areas including variational and linear inequalities, optimization and applications in the field of approximation theory and minimum norm problems, with the help of the various applications of fixed points of the contraction mappings.

Thus many authors are trying to strength the Banach contraction principle for a wide range of applications.

Let $(\mathrm{X}, \mathrm{d})$ be a nonempty metric space. A function $\alpha$ of $\mathrm{XxX}$ into $[0, \infty)$ is symmetric if $\alpha(\mathrm{x}, \mathrm{y})=\alpha(\mathrm{y}, \mathrm{x})$ for all $\mathrm{x}, \mathrm{y}$ in $\mathrm{X}$. Let $\mathrm{T}$ be a self mapping on $\mathrm{X}$. $\mathrm{T}$ is generalized nonexpansive if there exist symmetric functions $\alpha_{\mathrm{i}}, \mathrm{i}=1,2,3,4,5$, of $\mathrm{XxX}$ into $[0, \infty)$ such that

$$
\sup \left\{\sum_{i=1}^{n} \alpha_{i}(x, y): x, y \in X\right\} \leq 1 \longrightarrow
$$

and for every $\mathrm{x}, \mathrm{y} \in \mathrm{X}$.

$$
\begin{gathered}
\mathrm{d}(\mathrm{T}(\mathrm{x}), \mathrm{T}(\mathrm{y})) \leq \alpha_{1} \mathrm{~d}(\mathrm{x}, \mathrm{y})+\alpha_{2} \mathrm{~d}(\mathrm{~T}(\mathrm{x}), \mathrm{x})+\alpha_{3} \mathrm{~d}(\mathrm{~T}(\mathrm{y}), \\
\mathrm{y})+\alpha_{4} \mathrm{~d}(\mathrm{~T}(\mathrm{y}), \mathrm{x})+\alpha_{5} \mathrm{~d}(\mathrm{~T}(\mathrm{x}), \mathrm{y}) \longrightarrow(2)
\end{gathered}
$$

where $\alpha_{\mathrm{i}}=\alpha_{\mathrm{i}}(\mathrm{x}, \mathrm{y})$. And it is said to be generalized contraction if $\mathrm{T}$ satisfies (2) with

$$
\sup \left\{\sum_{i=1}^{n} \alpha_{i}(x, y): x, y \in X\right\}<1 \longrightarrow \text { (3) }
$$

R. Kannan first considered those $\mathrm{T}$ which satisfy (2) with $\alpha_{1}=\alpha_{4}=\alpha_{5}=0$ and $\alpha_{2}=\alpha_{3} \leq \frac{1}{2}$ [5], [6].

S. Reich considered those T which satisfy (2) with $\alpha_{4}=\alpha_{5}=0$ and with constants $\alpha_{1}, \alpha_{2}, \alpha_{3}$ [8].

$$
\mathrm{d}(\mathrm{T}(\mathrm{x}), \mathrm{T}(\mathrm{y})) \leq \alpha_{1} \mathrm{~d}(\mathrm{x}, \mathrm{y})+\alpha_{2} \mathrm{~d}(\mathrm{~T}(\mathrm{x}), \mathrm{x})+\alpha_{3} \mathrm{~d}(\mathrm{~T}(\mathrm{y}),
$$

y)

G. Hardy and T. Rogers, considered those continuous mappings $\mathrm{T}$ satisfying (2) with constants satisfy (3), [4].

K. Goebel, W. A.Kirk and Tawfik N. Shimi, proved that a continuous mapping $\mathrm{T}$ which satisfy (2) on a non weakly compact convex subset $\mathrm{C}$ of a uniformly convex Banach space into itself with constants satisfy (1) has a fixed point [3].

Chi Song Wong showed that, if $\mathrm{C}$ is a compact convex subset of a uniformly convex Banach space and $\mathrm{T}$ is a generalized nonexpansive self-mapping on $\mathrm{C}$, then the fixed point of $\mathrm{T}$ can be approximated by the iterates of $\mathrm{T}_{\mathrm{t}}$ with $\mathrm{t}(0,1), \mathrm{T}_{\mathrm{t}}(\mathrm{x})=(1-\mathrm{t}) \mathrm{x}+\mathrm{tT}(\mathrm{x}), \mathrm{x} \in \mathrm{C}[2]$.

Sahar Mohamed Ali, considered a contraction mapping defined on a closed convex subset of a weakly Cauchy normed space, spaces which are not necessarily be complete in general [7].

In this paper we considered the class of mappings $\mathrm{T}$ which are satisfy (2) with $\alpha_{4}=\alpha_{5}=0$ and with

Corresponding Author: $\quad$ Entisarat El-Shobaky, Department of Mathematics, Faculty of Science, Ain Shams University, Cairo, Egypt 
constants $\alpha_{1}, \alpha_{2}, \alpha_{3}$ satisfy (3), (such mappings are defined to be $\{a, b, c\}$-contraction mappings) and generalized the result of [7]. Equivalently we generalized the Banach contraction principle in two directions, first direction is a weaker assumption imposed on the given normed space, the weakly Cauchy normed space, and the other direction is a more general condition imposed on the given mapping. Also the $\{a, b, c\}$-contraction condition is valid only on a closed convex subset of the whole space.

More explicitly, we have the following definition

Definition1: A mapping $\mathrm{T}$ on a normed space $\mathrm{X}$ is said to be $\{a, b, c\}$-contraction, where $a, b$, and $\mathrm{c}$, are real numbers, $0 \leq \mathrm{a}, \mathrm{b}, \mathrm{c}$, and $\mathrm{a}+\mathrm{b}+\mathrm{c}<1$ if and only if $\|$ $\mathrm{T}(\mathrm{x})-\mathrm{T}(\mathrm{y})\|\leq \mathrm{a}\| \mathrm{x}-\mathrm{y}\|+\mathrm{b}\| \mathrm{T}(\mathrm{x})-\mathrm{x}\|+\mathrm{c}\| \mathrm{T}(\mathrm{y})-\mathrm{y}$ $\|$ for every $\mathrm{x}, \mathrm{y} \in \mathrm{X}$.

Notations and basic definition ${ }^{[3,6]}$ : A mapping $T$ on a normed space $X$ into $X$ is said to be contraction if and only if there is a non - negative real number $r<1$ with the property that $\|\mathrm{T}(\mathrm{x})-\mathrm{T}(\mathrm{y})\| \leq \mathrm{r}\|\mathrm{x}-\mathrm{y}\|$ for every $\mathrm{x}, \mathrm{y} \in \mathrm{X}$. A point $\mathrm{y} \in \mathrm{X}$ is said to be fixed point with respect to the operator $\mathrm{T}$ if and only if $\mathrm{T}(\mathrm{y})=\mathrm{y}$. As $\mathrm{T}$ is contraction, it preserves strong convergence, but it does not preserve weak convergence in general.

Let $\mathrm{X}$ be a linear space. Then a function $\mathrm{f}$ from $\mathrm{X}$ into $(-\infty, \infty]$ is said to be lower semi continuous and convex if it satisfies the following conditions:

* For any real number $\alpha$, the set $\{\mathrm{x} \in \mathrm{X}: \mathrm{f}(\mathrm{x}) \leq \alpha\}$ is closed convex subset of X (lower semi continuous).

* For any $x, y \in X$ and $t \in[0,1], f(t x+(1-t) y) \leq$ $t \mathrm{f}(\mathrm{x})+(1-\mathrm{t}) \mathrm{f}(\mathrm{y})$ (convex function).

A normed space $X$ is said to be weakly Cauchy normed space if and only if every Cauchy sequence in $\mathrm{X}$ is weakly convergent to an element $\mathrm{X}$ in $\mathrm{X}$. We have the following:

Lemma1: Let $X$ be a normed space and $T$ be $\{a, b, c\}-$ contraction operator. Then for any natural number $\mathrm{n}$ and $\mathrm{x}$ in $\mathrm{X}$, we have $\left\|\mathrm{T}^{\mathrm{n}+1}(\mathrm{x})-\mathrm{T}^{\mathrm{n}}(\mathrm{x})\right\| \leq\left(\frac{a+b}{1-c}\right)^{n} \|$ $T(x)-x \|$. In this case clearly, the sequence $\left\{\| T^{n+1}(x)\right.$ $\left.\mathrm{T}^{\mathrm{n}}(\mathrm{x}) \|\right\} \mathrm{n} \in \mathrm{N}_{\mathrm{N}}$ converges to zero.

Proof. Since $\left\|T^{n+1}(x)-T^{n}(x)\right\| \leq a\left\|T^{n}(x)-T^{n-1}(x)\right\|+b$ $\left\|\mathrm{T}^{\mathrm{n}}(\mathrm{x})-\mathrm{T}^{\mathrm{n}-1}(\mathrm{x})\right\|+\mathrm{c}\left\|\mathrm{T}^{\mathrm{n}+1}(\mathrm{x})-\mathrm{T}^{\mathrm{n}}(\mathrm{x})\right\|, \| \mathrm{T}^{\mathrm{n}+1}(\mathrm{x})-\mathrm{T}^{\mathrm{n}}(\mathrm{x})$ $\|\leq(\mathrm{a}+\mathrm{b})\| \mathrm{T}^{\mathrm{n}}(\mathrm{x})-\mathrm{T}^{\mathrm{n}-1}(\mathrm{x})\|+\mathrm{c}\| \mathrm{T}^{\mathrm{n}+1}(\mathrm{x})-\mathrm{T}^{\mathrm{n}}(\mathrm{x}) \|$, we have $(1-c)\left\|T^{n+1}(x)-T^{n}(x)\right\| \leq(a+b)\left\|T^{n}(x)-T^{n-1}(x)\right\|$, thus, $\left\|\mathrm{T}^{\mathrm{n}+1}(\mathrm{x})-\mathrm{T}^{\mathrm{n}}(\mathrm{x})\right\| \leq\left(\frac{a+b}{1-c}\right)\left\|\mathrm{T}^{\mathrm{n}}(\mathrm{x})-\mathrm{T}^{\mathrm{n}-1}(\mathrm{x})\right\|$, repeat the last step with the term $\left\|T^{\mathrm{n}}(\mathrm{x})-\mathrm{T}^{\mathrm{n}-1}(\mathrm{x})\right\|$ (n1)-times, we get the proof.

Corollary1: Let $\mathrm{X}$ be a normed space and $\mathrm{T}$ be $\{\mathrm{a}, \mathrm{b}$, c $\}$ - contraction operator. Then for any $\mathrm{x}$ and $\mathrm{y}$ in $\mathrm{X}$ the sequence $\left\{\left\|\mathrm{T}^{\mathrm{m}}(\mathrm{x})-\mathrm{T}^{\mathrm{m}}(\mathrm{y})\right\|\right\}_{\mathrm{m}} \in \mathrm{N}_{\mathrm{N}}$ converges to zero.

Proof: For any natural number $\mathrm{m}$, we have $\| \mathrm{T}^{\mathrm{m}}(\mathrm{x})$ $\mathrm{T}^{\mathrm{m}}(\mathrm{y})\|\leq \mathrm{a}\| \mathrm{T}^{\mathrm{m}-1}(\mathrm{x})-\mathrm{T}^{\mathrm{m}-1}(\mathrm{y})\|+\mathrm{b}\| \mathrm{T}^{\mathrm{m}}(\mathrm{x})-\mathrm{T}^{\mathrm{m}-1}(\mathrm{x}) \|$ $+\mathrm{c}\left\|\mathrm{T}^{\mathrm{m}}(\mathrm{y})-\mathrm{T}^{\mathrm{m}-1}(\mathrm{y})\right\|$. Use Lemma (1), we get $\| \mathrm{T}^{\mathrm{m}}(\mathrm{x})$ $-\mathrm{T}^{\mathrm{m}}(\mathrm{y})\|\leq \mathrm{a}\| \mathrm{T}^{\mathrm{m}-1}(\mathrm{x})-\mathrm{T}^{\mathrm{m}-1}(\mathrm{y}) \|+\left(\frac{a+b}{1-c}\right)^{m-1}[\mathrm{~b} \| \mathrm{T}(\mathrm{x})$ $-\mathrm{x}\|+\mathrm{c}\| \mathrm{T}(\mathrm{y})-\mathrm{y} \|]$, repeat the last step with the term $\left\|\mathrm{T}^{\mathrm{m}-1}(\mathrm{x})-\mathrm{T}^{\mathrm{m}-1}(\mathrm{y})\right\|$, we have $\left\|\mathrm{T}^{\mathrm{m}}(\mathrm{x})-\mathrm{T}^{\mathrm{m}}(\mathrm{y})\right\| \leq \mathrm{a}\{\mathrm{a} \|$ $\mathrm{T}^{\mathrm{m}-2}(\mathrm{x})-\mathrm{T}^{\mathrm{m}-2}(\mathrm{y}) \|+\left(\frac{a+b}{1-c}\right)^{m-2}[\mathrm{~b}\|\mathrm{~T}(\mathrm{x})-\mathrm{x}\|+\mathrm{c} \|$ $\mathrm{T}(\mathrm{y})-\mathrm{y} \|]\}+\left(\frac{a+b}{1-c}\right)^{m-1}[\mathrm{~b}\|\mathrm{~T}(\mathrm{x})-\mathrm{x}\|+\mathrm{c} \| \mathrm{T}(\mathrm{y})-$ $\mathrm{y} \|],\left\|\mathrm{T}^{\mathrm{m}}(\mathrm{x})-\mathrm{T}^{\mathrm{m}}(\mathrm{y})\right\| \leq \mathrm{a}^{2}\left\|\mathrm{~T}^{\mathrm{m}-2}(\mathrm{x})-\mathrm{T}^{\mathrm{m}-2}(\mathrm{y})\right\|+\{\mathrm{a}$ $\left.\left(\frac{a+b}{1-c}\right)^{m-2}+\left(\frac{a+b}{1-c}\right)^{m-1}\right\}[\mathrm{b}\|\mathrm{T}(\mathrm{x})-\mathrm{x}\|+\mathrm{c} \| \mathrm{T}(\mathrm{y})-\mathrm{y}$ || ], repeating the last steps (m-3)-times, we see that $\|$ $\mathrm{T}^{\mathrm{m}}(\mathrm{x})-\mathrm{T}^{\mathrm{m}}(\mathrm{y})\left\|\leq \mathrm{a}^{\mathrm{m}}\right\| \mathrm{x}-\mathrm{y} \|+\left\{\mathrm{a}^{\mathrm{m}-2}\left(\frac{a+b}{1-c}\right)+\mathrm{a}^{\mathrm{m}-}\right.$ $3\left(\frac{a+b}{1-c}\right)^{2}+\ldots+\mathrm{a}^{2}\left(\frac{a+b}{1-c}\right)^{m-3}+\mathrm{a}\left(\frac{a+b}{1-c}\right)^{m-2}+$ $\left.\left(\frac{a+b}{1-c}\right)^{m-1}\right\}[\mathrm{b}\|\mathrm{T}(\mathrm{x})-\mathrm{x}\|+\mathrm{c}\|\mathrm{T}(\mathrm{y})-\mathrm{y}\|], \| \mathrm{T}^{\mathrm{m}}(\mathrm{x})$ $-\mathrm{T}^{\mathrm{m}}(\mathrm{y}) \quad\left\|\leq \mathrm{a}^{\mathrm{m}}\right\| \quad \mathrm{x} \quad-\mathrm{y} \quad \| \quad+$
$a^{m-2}\left(\frac{a+b}{1-c}\right)\left[1+\left(\frac{a+b}{a(1-c)}\right)+\left(\frac{a+b}{a(1-c)}\right)^{2}+\ldots+\left(\frac{a+b}{a(1-c)}\right)^{m-3}+\left(\frac{a+b}{a(1-c)}\right)^{m-2}\right]$ [ b $\|\mathrm{T}(\mathrm{x})-\mathrm{x}\|+\mathrm{c}\|\mathrm{T}(\mathrm{y})-\mathrm{y}\|],\left\|\mathrm{T}^{\mathrm{m}}(\mathrm{x})-\mathrm{T}^{\mathrm{m}}(\mathrm{y})\right\| \leq \mathrm{a}^{\mathrm{m}}$ $\|\mathrm{x}-\mathrm{y}\|+a^{m-2}\left(\frac{a+b}{1-c}\right)\left[\frac{1-\left(\frac{a+b}{a(1-c)}\right)^{m-1}}{1-\left(\frac{a+b}{a(1-c)}\right)}\right][\mathrm{b}\|\mathrm{T}(\mathrm{x})-\mathrm{x}\|+\mathrm{c} \|$ $\mathrm{T}(\mathrm{y})-\mathrm{y} \|],\left\|\mathrm{T}^{\mathrm{m}}(\mathrm{x})-\mathrm{T}^{\mathrm{m}}(\mathrm{y})\right\| \leq \mathrm{a}^{\mathrm{m}}\|\mathrm{x}-\mathrm{y}\|+$ $\left(\frac{a+b}{a c+b}\right)\left[\left(\frac{a+b}{1-c}\right)^{m-1}-a^{m-1}\right][\mathrm{b}\|\mathrm{T}(\mathrm{x})-\mathrm{x}\|+\mathrm{c} \|$ 
$\mathrm{T}(\mathrm{y})-\mathrm{y} \|]$. Since both of the sequences $\left\{\mathrm{a}^{\mathrm{m}}\right\}_{\mathrm{m}} \in \mathrm{N}$ and $\left\{\left(\frac{a+b}{1-c}\right)^{m}\right\}_{\mathrm{m}} \in \mathrm{N}_{\mathrm{N}}$ are converging to zero, taking the limit as $\mathrm{m}$ tends to infinity completes the proof.

Corollary2: Let $\mathrm{X}$ be a normed space and $\mathrm{T}$ be $\{\mathrm{a}, \mathrm{b}$, c\} - contraction operator. Then for any $\mathrm{x}$ and $\mathrm{y}$ in $\mathrm{X}$ and any natural number $\mathrm{m}$ we have $\lim _{\mathrm{n} \rightarrow \infty} \| \mathrm{T}^{\mathrm{m}}(\mathrm{y})$ $\mathrm{T}^{\mathrm{n}}(\mathrm{x})\left\|\leq\left(\frac{1-c}{1-(a+b+c)}\right)\left(\frac{a+b}{1-c}\right)^{m}\right\| \mathrm{T}(\mathrm{y})-\mathrm{y} \|$. In this case clearly, the sequence $\left\{\lim _{\mathrm{n} \rightarrow \infty}\left\|\mathrm{T}^{\mathrm{m}}(\mathrm{y})-\mathrm{T}^{\mathrm{n}}(\mathrm{x})\right\|\right\}$ $\mathrm{m} \in{ }_{\mathrm{N}}$ converges to zero.

Proof: for any natural numbers $\mathrm{m}, \mathrm{n}$ and $\mathrm{m}<\mathrm{n}$, we have $\left\|\mathrm{T}^{\mathrm{m}}(\mathrm{y})-\mathrm{T}^{\mathrm{n}}(\mathrm{x})\right\| \leq\left\|\mathrm{T}^{\mathrm{m}}(\mathrm{y})-\mathrm{T}^{\mathrm{m}+1}(\mathrm{y})\right\|+\| \mathrm{T}^{\mathrm{m}+1}(\mathrm{y})$ $-\mathrm{T}^{\mathrm{m}+2}(\mathrm{x})\|+\ldots+\| \mathrm{T}^{\mathrm{n}-1}(\mathrm{y})-\mathrm{T}^{\mathrm{n}}(\mathrm{y})\|+\| \mathrm{T}^{\mathrm{n}}(\mathrm{y})-\mathrm{T}^{\mathrm{n}}(\mathrm{x}) \|$, using Lemma (1) and Corollary (2), we see that $\| \mathrm{T}^{\mathrm{m}}(\mathrm{y})$

$-\mathrm{T}^{\mathrm{n}}(\mathrm{x}) \| \leq\left\{\left(\frac{a+b}{1-c}\right)^{m}+\left(\frac{a+b}{1-c}\right)^{m+1}+\ldots+\left(\frac{a+b}{1-c}\right)^{n-1}\right\}$ $\|\mathrm{T}(\mathrm{y})-\mathrm{y}\|+\mathrm{a}^{\mathrm{n}}\|\mathrm{x}-\mathrm{y}\|+$ $\left(\frac{a+b}{a c+b}\right)\left[\left(\frac{a+b}{1-c}\right)^{n-1}-a^{n-1}\right][\mathrm{b}\|\mathrm{T}(\mathrm{x})-\mathrm{x}\|+\mathrm{c} \|$ $\mathrm{T}(\mathrm{y})-\mathrm{y} \|]\left\|\mathrm{T}^{\mathrm{m}}(\mathrm{y})-\mathrm{T}^{\mathrm{n}}(\mathrm{x})\right\| \leq\left(\frac{1-c}{1-(a+b+c)}\right)\{$ $\left.\left(\frac{a+b}{1-c}\right)^{m}+\left(\frac{a+b}{1-c}\right)^{n-l}\right\}\|\mathrm{T}(\mathrm{y})-\mathrm{y}\|+\mathrm{a}^{\mathrm{n}}\|\mathrm{x}-\mathrm{y}\|$ $+\left(\frac{a+b}{a c+b}\right)\left[\left(\frac{a+b}{1-c}\right)^{n-1}-a^{n-1}\right][\mathrm{b}\|\mathrm{T}(\mathrm{x})-\mathrm{x}\|+\mathrm{c} \| \mathrm{T}(\mathrm{y})$ - $\mathrm{y} \|$ ], taking the limit as $\mathrm{n}$ tends to infinity gives $\left\{\mathrm{a}^{\mathrm{m}}\right\}_{\mathrm{m}} \in \mathrm{N}$ and $\left\{\left(\frac{a+b}{1-c}\right)^{m}\right\}_{\mathrm{m}} \in \mathrm{N}$ tend to zero and the proof. The following is our generalized Theorem:

Theorem2: Let X be a weakly Cauchy normed space, $\mathrm{C}$ be a closed convex subset of $\mathrm{X}$ and $\mathrm{T}$ be $\{\mathrm{a}, \mathrm{b}, \mathrm{c}\}$ contraction mapping from $\mathrm{C}$ into $\mathrm{C}$. Then $\mathrm{T}$ has a unique fixed-point $\mathrm{y} \in \mathrm{C}$. Moreover for every $\mathrm{x} \in \mathrm{C}$ the sequence of iterates $\left\{\mathrm{T}^{\mathrm{n}}(\mathrm{x})\right\}_{\mathrm{n}} \in \mathrm{N}$ is converging strongly to $\mathrm{y}, \lim _{\mathrm{n} \rightarrow \infty} \mathrm{T}^{\mathrm{n}}(\mathrm{x})=\mathrm{y}$.

Proof: Let $\mathrm{x}$ in $\mathrm{C}$, since $\mathrm{T}$ is $\{\mathrm{a}, \mathrm{b}, \mathrm{c}\}$ - contraction on $\mathrm{C}$, the inequalities $\left\|\mathrm{T}^{\mathrm{n}+1}(\mathrm{x})-\mathrm{T}^{\mathrm{n}}(\mathrm{x})\right\| \leq\left(\frac{a+b}{1-c}\right)^{n} \| \mathrm{T}(\mathrm{x})-$ $\mathrm{x} \|$, insure that, if $l \leq \mathrm{m}$, we have, $\left\|\mathrm{T}^{\mathrm{m}}(\mathrm{x})-\mathrm{T}^{l}(\mathrm{x})\right\| \leq$
$\left(\frac{1-c}{1-(a+b+c)}\right)\left(\frac{a+b}{1-c}\right)^{l}\left[1-\left(\frac{a+b}{1-c}\right)^{m-l-1}\right]\|\mathrm{T}(\mathrm{x})-\mathrm{x}\|$, and in turns it shows that, the sequence $\left\{\mathrm{T}^{\mathrm{n}}(\mathrm{x})\right\}_{\mathrm{n}} \in \mathrm{N}$ is Cauchy sequence in $\mathrm{C} \subset \mathrm{X}$, since $\mathrm{X}$ is weakly Cauchy, the Cauchy sequence $\left\{\mathrm{T}^{\mathrm{n}}(\mathrm{x})\right\}_{\mathrm{n}} \in \in_{\mathrm{N}}$ is weakly convergent to some element $\mathrm{y} \in \mathrm{X}$.

But $\mathrm{C}$ is convex closed, it is closed in the weak topology as well, $\mathrm{y}$ in $\mathrm{C}$. We claim that the element $\mathrm{y}$ is the unique fixed point of T. To prove such a claim, let $l$ be any arbitrarily natural number and define the lower semi continuous convex real valued function $\mu_{l}$ on $C$ by the following formula: $\mu_{l}(\mathrm{x})=\left\|\mathrm{T}^{l}(\mathrm{y})-\mathrm{x}\right\|$ for any real number $\alpha$, the set $\mathrm{G}_{\mathrm{l} \alpha}:=\left\{\mathrm{x} \in \mathrm{C}: \mu_{l}(\mathrm{x}) \leq \alpha\right\}$ is closed convex subset of $\mathrm{C}$ and in particular, for any $\varepsilon>0$ the

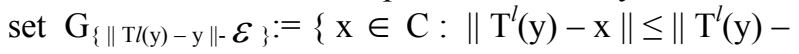
y $\|-\varepsilon\}$ is closed convex, hence it is closed in the weak topology, therefore its complement, $\mathrm{G}_{\{\|\mathrm{c} /(\mathrm{y})-\mathrm{y}\|-}$ $\varepsilon_{\}}:=\left\{\mathrm{x} \in \mathrm{C}:\left\|\mathrm{T}^{l}(\mathrm{y})-\mathrm{x}\right\|>\left\|\mathrm{T}^{l}(\mathrm{y})-\mathrm{y}\right\|-\varepsilon\right\}$ is weakly open set which containing $\mathrm{y}$, then there is a neighborhood $\mathrm{N}(\mathrm{y})$ of $\mathrm{y}$ such that $\left.\mathrm{N}(\mathrm{y}) \subset \mathrm{G}_{\{\|}^{\mathrm{c}} \mathrm{T} / \mathrm{y}\right)$ - y $\|$ $\varepsilon_{\}}$, on the other side, using the fact that y is the weak limit point of $\left\{\mathrm{T}^{\mathrm{n}}(\mathrm{x})\right\}_{\mathrm{n}} \in \mathrm{N}$, there is $\mathrm{n}_{0} \in \mathrm{N}$ such that $\mathrm{T}^{\mathrm{n}}(\mathrm{x}) \in \mathrm{N}(\mathrm{y})$ for every $\mathrm{n} \geq \mathrm{n}_{0}$, it follows that, $\| \mathrm{T}^{l}(\mathrm{y})$ $\mathrm{y}\|-\varepsilon<\| \mathrm{T}^{l}(\mathrm{y})-\mathrm{T}^{\mathrm{n}}(\mathrm{x}) \|$ for every $\mathrm{n} \geq \mathrm{n}_{0}$. We have two cases, the first is when $\mathrm{n}_{0} \leq l$, for such a case, one has $\left\|\mathrm{T}^{l}(\mathrm{y})-\mathrm{y}\right\|-\varepsilon<\left\|\mathrm{T}^{l}(\mathrm{y})-\mathrm{T}^{l}(\mathrm{x})\right\|$, which in turns, using Corollary (1), gives, $\lim _{l \rightarrow \infty}\left\|T^{\prime}(\mathrm{y})-\mathrm{y}\right\|-$ $\varepsilon=0$.

The other case, if $l<\mathrm{n}_{0}$, using Corollary (2), for that case, we see that $\operatorname{Lim}_{1, \mathrm{n} \rightarrow \infty}\left\|\mathrm{T}^{l}(\mathrm{y})-\mathrm{T}^{\mathrm{n}}(\mathrm{x})\right\|=0$, hence $\lim _{l \rightarrow \infty}\left\|\mathrm{T}^{l}(\mathrm{y})-\mathrm{y}\right\|-\varepsilon=0$. In both cases, we have $0 \leq \lim _{l \rightarrow \infty}\left\|\mathrm{T}^{l}(\mathrm{y})-\mathrm{y}\right\|<\varepsilon$ Since $\varepsilon$ is arbitrarily, one get $\lim _{l \rightarrow \infty}\left\|\mathrm{T}^{l}(\mathrm{y})-\mathrm{y}\right\|=0$, thus the sequence $\left\{\mathrm{T}^{\mathrm{n}}(\mathrm{y})\right\}_{\mathrm{n}} \in \in_{\mathrm{N}}$ converges strongly to $\mathrm{y}$. Finally, we have $\|\mathrm{y}-\mathrm{T}(\mathrm{y})\| \leq\left\|\mathrm{y}-\mathrm{T}^{\mathrm{n}}(\mathrm{y})\right\|+\| \mathrm{T}^{\mathrm{n}+1}(\mathrm{y})$ $-\mathrm{T}^{\mathrm{n}}(\mathrm{y})\|+\| \mathrm{T}^{\mathrm{n}+1}(\mathrm{y})-\mathrm{T}(\mathrm{y})\|\leq\| \mathrm{y}-\mathrm{T}^{\mathrm{n}}(\mathrm{y})\|+\| \mathrm{T}^{\mathrm{n}+1}(\mathrm{y})-$ $\mathrm{T}^{\mathrm{n}}(\mathrm{y}) \quad\|+\mathrm{a}\| \mathrm{T}^{\mathrm{n}}(\mathrm{y}) \quad-\quad \mathrm{y} \|$ $+\mathrm{b}\left\|\mathrm{T}^{\mathrm{n}+1}(\mathrm{y})-\mathrm{T}^{\mathrm{n}}(\mathrm{y})\right\|+\mathrm{c}\|\mathrm{T}(\mathrm{y})-\mathrm{y}\|$, Thus, (1-c) $\| \mathrm{y}-$ $\mathrm{T}(\mathrm{y})\|\leq(1+\mathrm{a})\| \mathrm{y}-\mathrm{T}^{\mathrm{n}}(\mathrm{y})\|+(1+\mathrm{b})\| \mathrm{T}^{\mathrm{n}+1}(\mathrm{y})-\mathrm{T}^{\mathrm{n}}(\mathrm{y}) \|$, Hence, $\|\mathrm{y}-\mathrm{T}(\mathrm{y})\| \leq\left(\frac{1+a}{1}\right)\left\|\mathrm{y}-\mathrm{T}^{\mathrm{n}}(\mathrm{y})\right\|+\left(\frac{1+b}{1+b}\right) \|$ $\mathrm{T}^{\mathrm{n}+1}(\mathrm{y})-\mathrm{T}^{\mathrm{n}}(\mathrm{y}) \|$, Since- $-1 \mathrm{eqm}_{\mathrm{n} \rightarrow \infty}\left\|\mathrm{y}-\mathrm{T}^{\mathrm{n}}(\mathrm{y})\right\| \overline{1=0}=$ $\lim _{\mathrm{n} \rightarrow \infty}\left\|\mathrm{T}^{\mathrm{n}+1}(\mathrm{y})-\mathrm{T}^{\mathrm{n}}(\mathrm{y})\right\|$, we see that $\mathrm{T}(\mathrm{y})=\mathrm{y}$ and $\mathrm{y}$ is a fixed point of $\mathrm{T}$. To show that $\mathrm{y}$ is unique, let $\mathrm{z}$ be another fixed point, we have the following contradiction, $\|\mathrm{y}-\mathrm{z}\|=\|\mathrm{T}(\mathrm{y})-\mathrm{T}(\mathrm{z})\| \leq \mathrm{a}\|\mathrm{y}-\mathrm{z}\|+\mathrm{b}$ $\|\mathrm{T}(\mathrm{y})-\mathrm{y}\|+\mathrm{c}\|\mathrm{T}(\mathrm{z})-\mathrm{z}\|=\mathrm{a}\|\mathrm{y}-\mathrm{z}\|<\|\mathrm{y}-\mathrm{z}\|$. To end the proof, let us show that the weak convergence of the sequence $\left\{T^{n}(x)\right\}_{n} \in N$ to the point $y$ is actually a 
strong convergence, since $\left\|\mathrm{T}^{\mathrm{n}}(\mathrm{x})-\mathrm{y}\right\|=\| \mathrm{T}^{\mathrm{n}}(\mathrm{x})-\mathrm{T}^{\mathrm{n}}(\mathrm{y})$ $\|$, using Corollary (1), we ends the proof.

The following Theorem is a more generalization of Banach contraction principle in the case of weakly Cauchy normed space.

Theorem3: Let $\mathrm{X}$ be a weakly Cauchy normed space, $\mathrm{C}$ be a bounded closed convex subset of $\mathrm{X}$, if $\mathrm{T}$ is contraction operator from $\mathrm{C}$ into itself, then $\mathrm{T}$ has a unique fixed point, $\mathrm{y}$ in $\mathrm{C}$. Moreover for every $\mathrm{x} \in \mathrm{C}$, the sequence of iterates $\left\{T^{n}(x)\right\}_{n} \in N$ is converging strongly to $\mathrm{y}$.

Proof: We only notice that the contraction mapping is $\{r, 0,0\}$ - contraction, then use Theorem 2 to get the proof.

Finally we have the following conclusion:

\section{CONCLUSION}

This paper suggested a new Theorem (1) which proved the existence of a unique fixed point of the generalized contraction mappings, namely $\{a, b, c\}$-contraction mappings. The $\{a, b, c\}$-contraction mapping defined on closed convex subset of a weakly Cauchy normed space, hence generalized the author's results given in references [4], [5], [6], and [7]. Based on the proved theorem, the given normed space $\mathrm{X}$ is not necessarily complete and the generalized contraction condition is valid only on a closed convex subset of $X$.

\section{REFERENCES}

1. El-Shobaky, E. M., Sahar Mohammed Ali and Wataru Takahashi, 2001. On The Projection Constant Problems And The Existence Of The Metric Projections in normed spaces. Abstr. Appl. Anal. 6 :no.7: 401-410.

2. Chi Song Wong, 1976 “ Proceedings of the American mathematical socity, volume 54.

3. K. Goebel, and W. A. Kirk, Tawfik . N. Shimi, 1973. A fixed Point theorem in Uniformly Convex Spaces., Boll. Un. Mat. Ital., (4) 7, 63-75.

4. H. Hardy and T. Rogers, 1973. "A generalization of a fixed point theorem of Reich Canada". Math. Bull., 16, 201-206.

5. R. Kannan, 1969. "Some results on fixed points II", Amer. Math, Monthly, 76, 405-408.

6. R. Kannan, 1971. "Some results on fixed points III", Fun. Math., 70, 169-177.

7. Sahar Mohamed Ali, 2006. "Reduced assumption in the Banach Contraction Principle" the international Journal of mathematics and Statistics USA Vol 2, No, 1, PP. 343-345.

8. S. Reich, 1972. "Fixed points in locally convex spaces", Math. Z., 125, 17-31.

9. Wataru, T.2000. Nonlinear Functional Analysis, Fixed Point Theory and its Applications. Yokohama Publishers, Yokohama. 